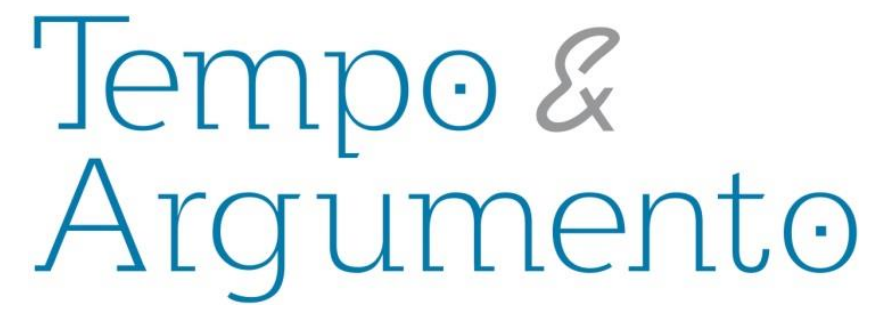

\title{
Cazumbá no pós-abolição: Memória, identidade e "patrimônio imaterial" em São Gonçalo dos Campos, Bahia
}

\begin{abstract}
Resumo
O artigo é parte de uma pesquisa maior que investigou a trajetória de uma família de descendentes de africanos que, desde o século XIX, mantém o sobrenome familiar, malgrado o regime de escravidão que, entre outras coisas, "abortava" o nome de família dos africanos escravizados e seus descendentes. Este artigo analisa a trajetória de um desses descendentes no pós-abolição, a partir da documentação escrita disponível e das narrativas orais acerca dos Cazumbá.
\end{abstract}

Palavras-chave: Patrimônio Imaterial. Pós-Abolição. Família.

\author{
José Bento Rosa da Silva \\ Doutor em História pela Universidade Federal \\ de Pernambuco (UFPE). Estágio Pós-Doutoral \\ na Université de Toulouse II - Le Mirail (UTM), \\ França. Professor na Universidade Federal de \\ Pernambuco (UFPE). \\ Recife - PE - Brasil \\ negrobento@bol.com.br
}

\section{Para citar este artigo:}

SILVA, José Bento Rosa da. Cazumbá no pós-abolição: Memória, identidade e "patrimônio imaterial” em São Gonçalo dos Campos, Bahia. Tempo e Argumento, Florianópolis, v. 10, n. 25, p. 115 - 143, jul./set. 2018.

DOI: $10.5965 / 2175180310252018115$

http://dx.doi.org/10.5965/2175180310252018115 


\title{
Cazumbá in post-abolition: \\ Memory, identity and \\ "immaterial patrimony" in \\ São Gonçalo dos Campos,
}

\section{Bahia}

\begin{abstract}
The article is part of a larger research that investigated the trajectory of a family of descendants of Africans who, since the nineteenth century, maintains the family surname, despite the slavery regime that, among other things, "aborted" the family name of the enslaved Africans and their descendants. This article analyzes the trajectory of one of these descendants in the post-abolition from the written documentation available and the oral narratives about the Cazumbá.
\end{abstract}

Keywords: Intangible Heritage. Post-Abolition.

Family.

Nossa investigação acerca da família Cazumbá, radicada no Recôncavo Baiano, revelou, através das fontes orais, que a memória dos entrevistados membros da família, quando perguntados sobre os antepassados, não ultrapassava a terceira geração, ou seja, nenhum deles soube falar sobre os bisavôs ou trisavôs, quando muito, lembraram-se dos avôs. Partimos do pressuposto de que a memória e/ou tradição oral seriam suportes, "pontas de icebergs" com as limitações que todos os documentos revelam; mas, no caso dos descendentes de africanos no Brasil, tais referências tornaram-se mais complexas devido ao passado escravista e suas permanências ainda latentes no tempo presente ${ }^{1}$. É muito raro encontrarmos diários ou outros escritos dos egressos do cativeiro feitos de próprio punho.

\footnotetext{
${ }^{1}$ O fato de o governo federal programar políticas específicas para combater o trabalho análogo ao trabalho escravo é uma prova dessa permanência.
} 
As entrevistas indicaram-nos que, no passado, a família Cazumbá possuía bens materiais, sobretudo terras, na cidade de São Gonçalo dos Campos, na localidade denominada Cruz ou Cruzeiro, que, de acordo com os memorialistas, seria o local do início do povoamento, e, segundo a tradição oral, onde teria aparecido uma imagem de São Gonçalo:

[...] Quando eu me mudei para cá, quem morava ali era João Cazumbá. É onde se diz que São Gonçalo apareceu. Todo ano fazia romaria para cá. [...] Conheci João Cazumbá, era meu compadre, era negro mesmo, alto. Ele e o pai de Betinho já moravam no corredor. João Cazumbá era tio de Betinho. A família Cazumbá é muito grande. Aqui na Lagartixa tem Cazumbá, na descida que vai para Salvador, tem um senhor que tem um bar, o Egídio, é Cazumbá. Luiz é filho de [pensa] não está bem na minha mente não. Manoel que é pai do Betinho. João era irmão de Manoel $[\ldots]]^{\prime 2}$

Lessa (2005) apresenta descrição da localidade publicada no jornal A Verdade, em 1937:

Era uma fazenda bem perto daqui. Lá para as bandas do sol posto. O seu proprietário, poderoso. Rico senhor, havia deliberado edificar ali uma grande cidade [...] E as primeiras casas foram construídas, o cruzeiro, o símbolo da fé ali plantado. E o prestígio e a bondade do senhor faziam afluir àquela terra grande número de pessoas que lutavam para vencer a sorte, facilitando o povoamento que se chamaria Cruzeiro [...] (Jornal A Verdade, ano I, n. 1, 31 jan. 1937 apud LESSA, 2005, p. 33-34)

Cotejando as informações de dona Carmosina, conhecida como Carmó, chegamos à conclusão de que o João Cazumbá, por ela citado, era na verdade, João Cardoso Cazumbá, um dos dez filhos de Gonçalo Cardoso Cazumbá com Maria Felipa Cerqueira, a “Maroca”. Gonçalo Cardoso colocara em um dos seus filhos o mesmo nome de seu pai: João Cardoso Cazumbá (sênior). Os demais filhos do casal chamavam-se: Manoel Cardoso Cazumbá Sobrinho, Silvano Cardoso Cazumbá, Carolina Cardoso Cazumbá, Demétrio Cardoso Cazumbá, Cecília Cardoso Cazumbá, Plácida Cardoso Cazumbá, Joana Cardoso Cazumbá, Maria Cerqueira Cazumbá e Lucinda Cardoso Cazumbá.

\footnotetext{
${ }^{2}$ Entrevista com Carmosina Brites de Oliveira, em 3 de fevereiro de 2011, em São Gonçalo dos Campos, na localidade da Cruz.
} 
Gonçalo Cardoso Cazumbá, por sua vez, era filho de João Cardoso Cazumbá ${ }^{3}$ e Rita Gonçalves de Oliveira, ex-escrava de Antônio Gonçalves de Oliveira. Pelo que tudo indica, tornara-se Gonçalves de Oliveira após a alforria. No registro de Gonçalo Cardoso Cazumbá, constava que o nome da mãe era Rita Gonçalves Cazumbá. Portanto, João Cardoso Cazumbá (sênior) e Rita já haviam contraído matrimônio por ocasião do registro de Gonçalo.

João Cardoso Cazumbá (sênior) gerou, além de Gonçalo, outros sete filhos, que foram reconhecidos por ele em abril do ano de 1888, praticamente um mês antes da abolição formal da escravidão (FMJM-SGCBA, 1887-1891, livro 8, folha 74). É certo que os debates acerca da abolição da escravidão estavam acalorados, inclusive os jornais liberais e abolicionistas veiculavam o que vinha se debatendo no parlamento. Como exemplo das notícias que vinham da Corte (Rio de Janeiro) e circulavam pelo interior do Brasil, podemos citar nota de um jornal do interior da Província de Santa Catarina acerca dos projetos abolicionistas:

\section{Da Corte:}

Recebemos, pelo vapor Rio Negro, jornais, que alcançam até 11 do corrente.

As notícias que encontramos, pouco adiantam as já sabidas. 0 parlamento encetando seus trabalhos, tem-se ocupado com a demissão do ex-Ministro da Guerra, com a febre do abolicionismo, havendo choques entre os srs. Deputados, porém concluídos todos a favor da abolição da escravatura, divergindo apenas sobre as formas. (JORNAL ITAJAHY, edição de 17 de maio de 1884, p. 3)

Como as ideias circulavam, é possível que João Cardoso Cazumbá tivesse ouvido algo a respeito e houvesse resolvido reconhecer os filhos gerados com Rita Gonçalves de Oliveira para garantir-Ihes o futuro próximo; ou talvez tenha tomado conhecimento do decreto-lei de 1887 acerca do registro civil $^{4}$, que previa a punição com multa e prisão dos

\footnotetext{
3 Para não confundirmos o neto, João Cardoso Cazumbá, com o avô que tem o mesmo nome, denominaremos o avô como: João Cardoso Cazumbá (sênior).

4 “O decreto $\mathrm{N}^{\circ} 3.316$, DE 11 DE JUNHO DE 1887. Approva, na parte penal, o Regulamento acerca do registro dos nascimentos, casamentos e obitos, e autorisa o Governo a reformar o mesmo regulamento" [sic]. Coleção das Leis do Império. Disponível em: <http://www2.camara.leg.br/legin/fed/decret/18241899/decreto-3316-11-junho-1887-542925-publicacaooriginal-52597-pl.html>.
} 
Vicente Cardoso Cazumbá, Francisco Cardoso Cazumbá, Manoel Cardoso Cazumbá, Joana Cardoso Cazumbá, Joaquina Cardoso Cazumbá e Claudina Cardoso Cazumbá (FMJMSGCBA, 1883-1886, livro 4, folha 74). A certidão de perfilhação omitiu a idade dos filhos reconhecidos, mas cotejando a data de falecimento de alguns, a partir de inventários, conseguimos identificar a idade aproximada no momento do reconhecimento. Havia alguns com idade acima de 21 anos de idade, como Gonçalo Cardoso Cazumbá, que estava com aproximadamente 34 anos $^{5}$.

Quem era mesmo esse João Cardozo Cazumbá? O que sabemos dele foi através do registro de compra e venda de terras e do processo de perfilhação dos filhos acima mencionados. Não identificamos, no rol dos documentos disponíveis no arquivo, o seu inventário, mas avistamos uma pista, como um caçador atrás de sua presa, não conseguimos capturá-las desta feita, e continuamos a manusear os processos empoeirados ${ }^{6}$. Paciência! Uma virtude inerente aos que desejam êxito em suas aventuras investigativas.

Enfim, encontramos uma escritura revelando que, em 1879, João Cardoso Cazumbá (sênior), em parceria com Manoel Ferreira de Cerqueira, comprou do major Francisco Antônio de Carvalho uma fazenda com benfeitorias, inicialmente denominada Várzea e posteriormente, Sobrado, pela quantia de um conto e oitocentos mil réis (um conto de réis equivalia a um milhão de réis, a um quilo de ouro e ao preço de um título de nobreza).

Segundo o documento de compra e venda, essa propriedade foi adquirida pelo major, em virtude da dívida que o finado comendador Antônio Lopes Ferreira e Souza

\footnotetext{
${ }^{5}$ Segundo o inventário de Gonçalo Cardoso Cazumbá, datado de 1945, ele morreu com 91 anos de idade. Portanto, nasceu em 1854. Foi reconhecido pelo pai em 1888, na época com a idade de 34 anos.

${ }^{6}$ Encontramos uma lista com os processos que deveriam estar no arquivo, mas que não se encontravam de fato no referido arquivo. Na referida lista, constava o seguinte: Ano: 1891/Inventariante: Donata Pedreira do Sacramento/Falecido: João Cardoso Cazumbá/N. da folha: 30v-31/N. da relação:036. FMJM-SGCBA. Setor: Cartório Cível: inventários a partir de 1860. Índice de processos julgados, inventários e arrolamentos. P. de 2 a 100.
} 
terras hoje fazem parte da localidade denominada Cruz ou Cruzeiro, próxima da rodovia que liga à cidade de Cachoeira, antiga estrada real, por ali haver passado o Imperador Pedro II, quando em visita à região. As fontes orais corroboram a documentação. E mais: há ainda alguns poucos descendentes de João Cardoso Cazumbá (sênior) que moram na localidade, um dos territórios historicamente habitados pelos Cazumbá na cidade de São Gonçalo dos Campos.

Seguindo a classificação que Cléber Moraes Freire (2007) elaborou, visando caracterizar as grandes fortunas da região de Feira de Santana no século XIX, a propriedade adquirida por João Cardoso Cazumbá (sênior) e seu parceiro estaria entre as pequenas $^{8}$, embora o documento não especifique o tamanho da propriedade, limitandose a dizer "[...] tudo por braças e estradas, cujas terras assim demarcadas e divididas [...]”. A classificação de Freire foi calculada a partir do valor das propriedades. A fazenda Cazumbá foi avaliada em 1:800\$000 (um conto e oitocentos mil réis).

O terreno vinha de uma demanda judicial, como se depreende da escritura de compra e venda:

[...] E logo pelo referido vendedor me foi dito na presença das testemunhas no fim declaradas e assinadas, que era senhor e legítimo possuidor das terras, casas e benfeitorias da fazenda, antigamente denominada Várzea e hoje Sobrado, cuja Ihe foi adjudicada pelo juiz de órfãos da cidade de Santo Amaro, Joaquim, -digo- Amaro, doutor Joaquim [...] de Almeida Freitas por parte dos sucessores do finado comendador Antônio Lopes Ferreira e Souza que era seu devedor e a quem pertencia a referida fazenda [...] (FMJM-SGCBA, anos 1879-1881, livro n. 2, folhas 10v-11)

\footnotetext{
${ }^{7}$ Na relação dos padres que foram vigários na Igreja de São Gonçalo do Amarante (fundada em 1696), não identificamos o nome do padre Gonçalo de Souza, mas o do padre Gonçalo Martinho Falcão (1787).

${ }^{8}$ De acordo com Freire (2007), os valores das pequenas propriedades estariam entre 615\$000 e 5:000\$000; das médias baixas entre 5:001\$000 e 20:000\$000; das médias entre 20:001\$000 e 50:000\$000; das médias altas entre 50:001\$000 e 100:000\$000; das grandes baixas entre 100:001\$000 e 200:000\$000; das grandes médias entre 200:001\$000 e 500:000\$000; das grandes entre 500:001\$000 a 1.000:000\$000; e das muito grandes acima de 1.000:000\$000.
} 
As referidas terras estavam localizadas no arraial pertencente à freguesia de São Gonçalo dos Campos, ou seja, São Gonçalo não se constituía ainda como uma vila, pertencia à Vila de Cachoeira, da qual se emancipara em 1884. Por essa época, a principal fonte econômica da região era o cultivo do fumo, que, na História do Brasil, entre outras coisas, serviu como "moeda" para aquisição de escravos no continente africano (VERGER, 1987). A localização geográfica de São Gonçalo também precisa ser considerada no contexto da trajetória Cazumbá, pois as terras adquiridas eram contíguas a uma importante via de comunicação que levava a Cachoeira, Feira de Santana e à capital, São Salvador da Bahia:

[...] A sua posição geográfica e as estradas de boiada que cortam o seu território Ihe asseguraram, desde os tempos em que havia toda a influência do açúcar, do fumo e do Porto de Cachoeira, principal escoadouro de comercialização para onde chegavam as mercadorias que se destinavam ao sertão ou que vinham e se dirigiam a Salvador [...] (LESSA, 2005, p. 31)

Nessas atividades econômicas, a presença de escravizados africanos e crioulos foi imprescindível, com a ressalva de haver peculiaridades, quais sejam, enquanto a produção açucareira exigia um sistema de "plantation", a economia fumageira era de pequena propriedade. Nesse tipo de produção, segundo Lessa (2005, p. 50), "havia um número expressivo de escravos velhos e doentes e aleijados, a cultura do fumo estava associada à pobreza, dentro deste quadro, o feitor era desnecessário".

Não sabemos inicialmente qual foi o cultivo dado às terras adquiridas por João Cardoso Cazumbá (sênior) e Manoel Ferreira de Cerqueira; tampouco como a propriedade foi dividida para o cultivo. Sabemos, no entanto, que, passados seis anos, João Cardoso Cazumbá (sênior) comprou um escravo para os serviços da lavoura: João, de dezenove anos de idade, solteiro, adquirido de Dona Ana Joaquina Ferreira de Cerqueira pelo valor de $350 \$ 000$ (trezentos e cinquenta mil réis).

Embora tenha comprado o escravo individualmente, sem a presença do parceiro, Manoel Ferreira de Cerqueira, a negociação tinha o seu envolvimento. E mais, Cazumbá (sênior) comprara o escravo João de um outro Cerqueira, dona Ana Joaquina. Embora não saibamos qual o laço de parentesco que esta tinha com Manoel Ferreira Cerqueira, 
[...] João, preto, de idade de 19 anos, mais ou menos, solteiro, do serviço da lavoura, natural desta freguesia, o qual fora matriculado pela coletoria geral de Cachoeira por José Ferreira de Cerqueira, averbado e matriculado a Manoel Ferreira de Cerqueira em 11 de agosto de 1877 [...] 6645 da matrícula geral e quatro da ordem da relação [...] o qual o escravo vendo e vendido tinha de hora em diante, a João Cardoso Cazumbá pela quantia de 350 mil réis [...] (FMJM-SGCBA, anos 1883 a 1886, livro 4, folha 74)

O escravo foi vendido por Ana Joaquina de Cerqueira, mas estava registrado na coletoria, cujo coletor também era um Cerqueira, Manoel Ferreira de Cerqueira, o mesmo que comprara a fazenda com ele. E mais, o registro de João a Manoel Ferreira de Cerqueira foi feito dois anos antes da compra da fazenda. É possível que o registro tenha sido feito por Manoel porque Ana Joaquina não sabia ler nem escrever, assim como João Cardoso Cazumbá (sênior). No ato da compra e venda, quem assinou por João Cardoso Cazumbá foi Lindolpho de Souza Machado; pela vendedora, assinou Manoel Joaquim Ferreira de Cerqueira.

Nas leituras dos processos sobre os Cazumbá manuseados nos arquivos do Fórum de São Gonçalo dos Campos, encontramos marcas de leituras anteriores, com grifos sobre nomes de membros da família, indicando que os processos foram lidos em tempo anterior à nossa pesquisa, possivelmente por advogados em busca de argumentos para demandas judiciais a respeito das terras após o falecimento de João Cardoso Cazumbá (sênior). Demandas que nos remetem a alguns depoimentos acerca de como os Cazumbá perderam as suas terras ao longo da primeira metade do século XX. Embates jurídicos que levaram anos em torno de propriedades entre Cazumbá e outros na localidade da Cruz, como apontam os processos e as fontes orais: "As terras eles foram roubados, eu ouvia falar que aquele pessoal que tinha dinheiro, - com inveja - [...] os maridos das minhas tias faziam as vendagens, sem falar com as donas das propriedades, quando chegavam era os homens já levando, tirando [...] eu ouvia falar assim [...]" (Entrevista com Rosa de Lima Cazumbá Gomes). 
A verdade é que as terras adquiridas por João Cardoso Cazumbá (sênior), em 1879, foram alvo de disputas após a sua morte. Ouvimos mais depoimentos com referências às terras da Fazenda Cruz, onde moravam os antepassados. Alguns lá passaram a infância, antes de mudarem-se para a cidade de São Gonçalo. São memórias que falam do trabalho e do cotidiano daquelas terras, como o de Cazumbá I, que, na época da entrevista, estava com 84 anos de idade, e de Cazumbá VIII, que fora casada com um bisneto de João Cardoso Cazumbá (sênior), Mathias Cazumbá. Ela diz lembrar-se das terras dos sogros e de como eram altivos os Cazumbá daquela época:

[...] Eu me casei com Mathias Cazumbá, o pai dele era Manoel Cazumbá, a mãe era Cesária. Eles tinham boi, tinham porco, plantavam fumo, plantavam arroz, tinha cavalo, galinhas, plantavam mandioca, vendiam [...] Meu marido mesmo vendeu a terra do pai com casa com tudo por R\$ $60.000,00$ (sessenta mil reais). Ali era tudo dos Cazumbá. Aqui neste lado mesmo era tudo Cazumbá [...] eu fui casada com Cazumbá, mas naquele tempo os antigos não davam trela, se chegasse na casa eles estivessem lá dentro, não vinham atender. Os negros (Cazumbá) só andavam de linho, bem arrumados, como doutores! Sapato branco nos pés! [...] (Entrevista com Maria da Invenção Cazumbá)

Após a morte de João Cardoso Cazumbá (sênior) em 1891, o primeiro processo que encontramos relativo às terras por ele adquiridas com Manoel Ferreira de Cerqueira ocorreu em 1896, cinco anos após seu falecimento. Um dos seus oito filhos, Manoel Cardoso Cazumbá, comprou de Venceslau Pereira Sena, pela quantia de 530\$000 (quinhentos e trinta mil réis). Pela descrição do imóvel, parece-nos parte daquele comprado há dezessete anos por João Cardoso Cazumbá (sênior) e o seu parceiro. Possivelmente a parte que foi de Manoel Ferreira de Cerqueira, pois fazia fronteira com terras de seu irmão Vicente Cardoso Cazumbá:

[...] um sítio denominado "Cruz" nesta freguesia e vila, contendo terras de lavoura, casa de morar e benfeitorias, divisando-se o terreno pela frente com a estrada real da Feira de Santana, pelos fundos com a estrada de ferro de Cachoeira e Feira, por um lado com o corredor das terras divisórias de Chico Lourenço com as terras de Cazumbá e pelo outro lado com as terras de Vicente Cazumbá [...] (FMJM-SGCBA, livro 13, anos 1895-1896, folha 18)

Tanto o vendedor, Venceslau, quanto o comprador, Manoel Cardoso Cazumbá, eram lavradores, residentes em São Gonçalo. Manoel sabia ler e escrever, mas Venceslau 
Numa sociedade, na qual, como frisou Silva (2001), a escolaridade não era incentivada, saber o mínimo das primeiras letras, sobretudo para população negra, cuja trajetória era o trabalho nas lavouras, era um diferencial. Manoel, segunda geração dos Cazumbá, foi o único dos irmãos que assinara documento de compra e venda de imóveis, os demais recorreram a terceiros.

As terras descritas na escritura são as mesmas mencionadas por Cazumbá XII quando falava-nos sobre o território Cazumbá: “[...] Tinha terra lá embaixo (o avô), até lá na beira do rio. Foi vendendo [...] A gente morava lá embaixo, quando vinha o trem, a gente corria para ver o trem. $\mathrm{O}$ trem cheio de gente. A gente ficava vendo o pessoal e acenando [...]" (Entrevista com Ana Regina Cazumbá de Queiroz). Lembranças a partir da infância, década de quarenta do século XX. Quando a entrevistamos, ela, filho, nora e netos continuavam morando na região da Cruz, mas num espaço bem reduzido, se comparado com as terras adquiridas pelos antepassados, no caso específico, por seu bisavô, João Cardoso Cazumbá (sênior) e pelo avô Manoel Cardoso Cazumbá.

Manoel Cardoso Cazumbá comprou uma casa na mesma localidade, fazendo confluência com as terras de seus irmãos, dois anos depois da aquisição acima mencionada. Comprou de Francisco Ferreira de Almeida e sua mulher por 600\$000 (seiscentos mil réis). Essa casa havia sido hipotecada, mas, segundo a documentação, estava quitada. Pela descrição do imóvel, não era uma casa pequena, pois tinha cinco portas, duas janelas e compartimentos. Manoel estava fazendo investimentos no início de um novo regime ${ }^{9}$, talvez se precavendo do que pudesse vir pela frente:

[...] Eu, tabelião compareci a seu chamado para lavrar a presente escritura, ali presentes, como vendedor, o dito Francisco Ferreira de Almeida e, como comprador, Manoel Cardoso Cazumbá, lavradores, moradores neste termo e reconhecidos próprios de mim, tabelião, do que dou fé; perante as testemunhas abaixo declaradas e assinadas, me foi dito pelo primeiro outorgante que, sendo senhor e possuidor de uma

\footnotetext{
${ }^{9}$ A República havia sido proclamada há menos de dez anos e alguns movimentos contestatórios ainda "pipocavam" pelo país no alvorecer do novo regime, dentre os quais a Revolta da Armada, Canudos e a Revolução Federalista.
} 
casa no lugar denominado "Cruz" deste termo e freguesia de São Gonçalo dos Campos, situada em terrenos dos herdeiros do finado João Cazumbá, a qual casa tem cinco portas e duas janelas, com seus repartimentos [...]. Disse mais, que esta casa está compreendida em uma hipoteca que fizeram com o cidadão Joaquim de Oliveira Torres, que se acha presente, por escritura lavrada em 4 de março de 1895, inscrita no registro hipotecário deste termo sob o n.16 do protocolo e n. 5 página primeira do livro número dois, inscrição especial, mas sendo pago parte da dívida ao credor hipotecário equivalendo ao valor da dita casa, e com o comprometimento do mesmo credor que fazem a presente venda, assinando ele mesmo esta escritura como testemunha. Presente o dito credor Joaquim de Oliveira Torres, declarou por sua vez, que considerava a dita casa exonerada do referido ônus por estar pago o valor da mesma relativamente à hipoteca a ser feita pelo que assinava esta escritura como testemunha. Pelo comprador foi dito que aceitava esta escritura com todas as suas declarações [...] (FMJM-SGCBA. anos 1898-1899, livro 15, folha 28.)

O ano de 1903 parece ter sido decisivo para o destino das terras adquiridas por João Cardoso Cazumbá (sênior). Foi o ano em que se concretizou a demarcação legal das terras dos Cazumbá e seus vizinhos.

\section{3: "o ano que não acabou"}

No dia $1^{\circ}$ de setembro do ano de 1903 , foi encaminhada ao juiz municipal de São Gonçalo dos Campos uma petição assinada por Odilon Borges Falcão, Manoel Ferreira Oliveira, Joaquim Ferreira de Oliveira, (a pedido de Maria Joaquina de Jesus), Antônio Carlos Pedreira (a pedido de Rita Cazumbá), José Machado Pedreira (a pedido de Gonçalo Cazumbá) e Luiz Cardoso Cazumbá (a pedido de Joana Cardoso Cazumbá). A petição solicitava a demarcação das terras desses proprietários que eram contíguas, e ao que nos parece, não estavam devidamente definidas. Talvez fossem "divisas cantadas" 10 , uma forma tradicional de demarcação de terras no interior do Brasil, sobretudo antes da terra "metamorfosear-se" em mercadoria.

${ }^{10}$ O filme Narradores de Javé, de Eliane Caffé, aborda a prática de demarcação de terras através das chamadas divisas cantadas. Em texto de análise sobre a produção cinematográfica, o Portal do Núcleo Piratininga de Comunicação descreve como se dá tal prática: "O que são divisas cantadas? 'O cabra cantava: daquela árvore no sopé do morro até a ponte perto do poço, digo que é tudo meu', explica Zaqueu [um dos personagens do filme]. São as divisas, os limites da propriedade ou de territórios, definidas apenas pela intenção de possuí-la. Obviamente, algo assim teria que ser negociado. Não poderia ser imposto por um poder econômico ou político. São lembranças de épocas muito remotas. Em que havia abundância de terras e falta de instrumentos de poder [...]" (NÚCLEO PIRATININGA DE COMUNICAÇÃO LINGUAGEM, 2006). 
Segundo a petição lavrada pelo escrivão, Lindolfo da Silva Machado, a demarcação foi uma decisão amigável entres as partes. O primeiro nome da petição é de Odilon Borges Falcão, quem tomara iniciativa da demarcação. E mais, entre os interessados, estava Rita Cazumbá, viúva de João Cardoso Cazumbá (sênior), e seus filhos: Gonçalo e Joana. Não constam os nomes dos outros filhos de Rita e João Cardoso Cazumbá, a saber: Marcelino, Vicente, Francisco, Manoel, Joaquina e Claudiana. Nenhum dos proprietários Cazumbá sabia ler e escrever, logo, o documento foi assinado por terceiros a pedido deles. Quem assinou para Joana Cazumbá foi Luiz Cardoso Cazumbá, neto de Manoel Cardoso Cazumbá, sobrinho-neto de Joana ${ }^{11}$.

Por essa época, Luiz Cardoso Cazumbá, “irmão carnal” (unilateral) de Cazumbá XII - que entrevistamos - já era maior de idade, pois assinara o documento a pedido da tiaavó, e mais, já tinha um filho natural, que reconhecera posteriormente ${ }^{12}$. Luiz Cardoso Cazumbá foi negociante e empresário na cidade de São Gonçalo dos Campos, na primeira metade do século XX, como se verá adiante. Parece ter seguido a experiência do avô, Manoel Cardoso Cazumbá, que, no início do século XX, comprara terras na localidade da Cruz. Talvez o domínio das leituras e das escritas, que ambos tiveram, tenha facilitado a atuação no mundo dos negócios e investimentos.

Não sabemos efetivamente quais as razões e condições que levaram os proprietários e vizinhos, em comum acordo, a optarem pela delimitação das terras. Essa demarcação foi mencionada em transações posteriores. Às vezes, os nomes Fazenda Cruz e Terra Dura foram confundidos na documentação - ao invés de Fazenda Terra Dura, registrou-se Fazenda Cruz. Vejamos como ficou a demarcação, inclusive visualizada por um croqui contido no processo:

\footnotetext{
${ }^{11}$ Luiz Cardoso Cazumbá era sobrinho-neto de Joana Cardoso Cazumbá, filho natural de Manoel Cardoso Cazumbá Filho. Na documentação investigada, não identificamos o nome da mãe, mas, cotejando as fontes escritas e orais, esboçamos um croqui da genealogia da família Cazumbá.

${ }^{12}$ Em 6 de setembro de 1920, Luiz Cardoso Cazumbá reconheceu ser pai de Anfilho Leonidio Cardoso de Amorim, filho que tivera com Maria Cyrila de Amorim. Leonidio nasceu em 31 de outubro de 1900. (APEB. Registro Civil. Escritura de Perfilhação. Tabelião: Luciano de Carvalho Marbak. Cartório: 90. Livro: 1294. p. 94-94v. Interessado: Luiz Cardoso Cazumbá. Parte: Anfilho Leonidio Cardoso de Amorim).
} 
IImo. Sr. Dr. Juiz preparador.

São Gonçalo dos Campos, 5 de setembro de 1903.

Odilon Borges Falcão, senhor e possuidor da Fazenda Cruz, Manoel Ferreira Oliveira e os senhores Maria Joaquina de Jesus, Rita Cazumbá, Gonçalo Cardoso Cazumbá e Joana Cazumbá, possuidores da fazenda Terra Dura; Tibúrcio Alves Barreiras e sua senhora, Maria Guilhermina Barreiras, proprietários da fazenda Cruz, todos deste termo, tendo entre si amigavelmente e de comum acordo realizado a demarcação e limites das fazendas acima, com a Fazenda Cruz do primeiro suplicante, com as das últimas, tendo conforme se evidencia dos documentos juntos do engenheiro Manoel Accioli Ferreira da Silva, e de acordo e obrigação entre os suplicantes sobre a referida demarcação e limite de terras, pedem a Vossa Excia. que digne mandar autuar a presente com os referidos documentos, e que selados e preparados os autos, subam á conclusão do meritíssimo sr. dr. Juiz de direito da comarca para a respectiva homologação.

Termos em que pede.

São Gonçalo, $1^{\circ}$ de setembro de 1903 [...] (FMJM-SGCBA, 1903) $)^{13}$

Do documento se depreende que a Fazenda Cruz tinha mais que um proprietário, ou que o nome Fazenda Cruz abrangia duas propriedades: as terras de Odilon Borges Falcão e as de Tibúrcio Alves Barreiras (e sua esposa Maria Guilhermina Barreiras); e a Fazenda Terra Dura, cujos proprietários eram Manoel Ferreira Oliveira (e sua esposa Maria Joaquina de Jesus), Rita Cazumbá, Gonçalo Cazumbá e Joana Cazumbá.

As terras que João Cardoso Cazumbá, juntamente com Manoel Ferreira de Cerqueira, adquiriu em 1879 situavam-se na mesma região, mas, na época, a denominação era Sobrado, e no passado havia sido Várzea. Os primeiros vizinhos eram: ao sul, as terras de João Maya Machado, ao oeste, as terras dos descendentes de Pedro Gonçalo de Souza, e ao leste com as terras de Estevão Machado. Não identificamos nenhum deles como vizinhos dos proprietários que demarcaram as suas terras, passados vinte e quatro anos da compra efetuada por João Cazumbá e Manoel Ferreira de Cerqueira. Talvez já tivessem vendido as propriedades para outrem, quem sabe para os que agora reivindicavam a demarcação.

\footnotetext{
${ }^{13}$ Esse processo não constava na lista dos existentes no arquivo do Fórum de São Gonçalo dos Campos. Encontramo-lo em virtude de nossa garimpagem no referido arquivo. Estava em condições deploráveis, como uma dezena de outros, pois o recinto é insalubre, com goteiras, fungos, traças, ácaros, todos inimigos declarados da pesquisa histórica.
} 
Qualquer processo jurídico tem um preço. O de demarcação das terras em questão custou 2.000\$000 (dois mil réis), valor pago pelo suplicante, Odilon Borges Falcão, à coletoria estadual em 5 de setembro de 1903.

O ponto de partida da demarcação das terras foi um marco de pedra, situado entre dois valos pertencentes a Odilon Borges e aos herdeiros de João Cardoso Cazumbá (sênior). Como se vê, as divisas não se constituíam de cercas, mas de referências "arcaicas", tais como marcos de pedras e acidentes geográficos: a lagoa, o rio. Mas Odilon já tinha uma parte de suas terras demarcadas com cerca de arame:

\section{[...] Ponto de partida.}

Parte de um marco de pedra situado num corredor entre dois valados pertencentes ao senhor Odilon Borges Falcão e aos herdeiros de João Cardoso Cazumbá e segue como rumo de $74^{\circ}$.N.O. até um outro marco de pedra e mede 187.00 . Dali seguindo com os mesmos $74^{\circ}$.N.O. e pelo mesmo corredor encontrei um outro marco de pedra ficando assim verificado a direção do rumo e mede mais 180.00. Continuando como o referido rumo de $74^{\circ}$.N.O. Acompanhando os respectivos (dados) cheguei a uma cerca de arame pertencente ao senhor Odilon Borges e mede mais 229.00. Prosseguindo na mesma direção, margeando a dita cerca até o fim desta, mede mais até um marco de pedra 864.00. Nesta frente existe uma lagoa denominada Tanquinho em cuja margem está colocado o último marco referido.

Ali presentes as terras confinantes [...] estes faz-se um desvio de rumo para a direita, desvio este de $7^{\circ}$.

Em obediência [...] a este [...] segue do dito marco até a margem do rio Jacuípe, fim do rumo e mede mais 4.540. Ficando assim terminada a presente divisa, com este último rumo que tem a direção de $67^{\circ}$.

São Gonçalo dos Campos, Fazenda Cruz, $1^{\circ}$ de setembro de 1903.

Engenheiro Manoel Accioli Ferreira da Silva.

$\mathrm{Na}$ qualidade de serem confinantes com a fazenda Cruz respeitamos para sempre o rumo descrito no presente memorial [...] (FMJM-SGCBA, 1903)

No mesmo processo, às folhas seguintes, consta outra peça jurídica importante na compreensão da trajetória da herança legada por João Cardoso Cazumbá (sênior). Tratase do primeiro traslado de escritura pública, que consiste na primeira via da escritura. Mas, algumas questões nos chamaram a atenção nesse documento: embora a demarcação tenha sido feita nos primeiros dias de setembro, como se viu acima, a data 
do primeiro traslado é do dia 29 agosto, ou seja, anterior à demarcação; na referida escritura constam as seguintes denominações: Fazenda Cruz, Fazenda Terra Dura e Fazenda Cazumbá. No processo de demarcação, foram mencionadas divisas com herdeiros de João Cardoso Cazumbá. É importante lembrar que nem todos os descendentes de João Cardoso Cazumbá participaram do processo de demarcação, somente Rita, a viúva, Gonçalo e Joana, dois dos oito filhos.

Cotejando as duas peças, notamos algumas alterações na redação: por exemplo, na primeira versão, não foi mencionado que o marco de pedra próximo do lago Tanquinho era de uma antiga ruína, que a divisa ao rumo norte-oeste ia até o rio Jacuípe; no documento de demarcação não foi mencionada a existência de Fazenda Cazumbá, mas terras dos herdeiros de João Cardoso Cazumbá. Por fim, esse documento foi redigido na Fazenda Cruz, propriedade de Odilon Borges, não no cartório. São particularidades que não constam na peça anterior de demarcação das terras, elaborada pelo mesmo escrivão Lindolfo da Silva Machado. Não sabemos ao certo que implicações jurídicas possam ter, mas uma coisa é certa: o translado de escritura pública consiste na primeira via da escritura. Segundo o Fórum Imobiliário (2011):

Sempre que se lavra uma escritura pública, a parte que tenha participado da escritura recebe o que se chama de 'traslado', ou seja, a primeira via da escritura. Se houver necessidade de mais vias, então o tabelião providenciará uma certidão dando conta do ato que está formalizado por meio da respectiva escritura pública. No valor pago a título de emolumentos ao tabelionato, está incluído o custo de um traslado da escritura; as certidões, entretanto, são cobradas em separado.

Vejamos o que consta no primeiro traslado de escritura pública das referidas terras:

[...] Primeiro traslado de escritura pública de acordo sobre demarcação e limites de terras ou como em direito, melhor mesmo tenho entre as partes: Odilon Borges Falcão; Manoel Ferreira de Oliveira e sua mulher, Maria Joaquina de Jesus; Rita Cazumbá; Gonçalo Cazumbá; Joana Cazumbá; Tibúrcio Alves Barreiros e sua mulher dona Guilhermina Barreiros, como adiante se declaram, lançados nos livros de notas, número 06 às folhas 86.

Saibam quantos este público instrumento de escritura pública de acordo sobre demarcação de terras, ou como em direito melhor mesmo tenho, 
que sendo no ano de 1903, aos 29 dias do mês de agosto do dito ano, na cidade de São Gonçalo dos Campos, comarca de Cachoeira, na fazenda denominada Cruz, na residência do cidadão Odilon Borges Falcão, onde eu tabelião, a chamado vim, ali compareceram os outorgantes: Odilon Borges Falcão, senhor e proprietário da fazenda Cruz; Manoel Ferreira de Oliveira e sua mulher, dona Joaquina De Jesus; Rita Cazumbá, Gonçalo Cazumbá e Joana Cazumbá, proprietários da fazenda denominada Terra Dura; Tibúrcio Alves Barreiras e sua mulher, dona Maria Gulhermina Barreiras, senhores e legítimos possuidores da fazenda denominada Cruz; todas situadas neste termo, sendo outorgantes proprietários lavradores residentes nesta cidade, reconhecidos próprias de mim, tabelião, do que dou fé e perante as testemunhas abaixo declaradas e assinada, disseram que tem demarcado amigavelmente de comum acordo as terras das fazendas denominada Cruz, Cazumbá e Terra Dura; segue em linha reta até uma pedra da antiga ruína colocada á margem Este (Oeste) de uma lagoa denominada Tanquinho; dali por comum acordo entre todos, segue um novo rumo com sessenta e sete N.O. até encontrar o Rio Jacuípe, termo da fazenda cruz, hoje pertencente a Tibúrcio Alves Barreiros.

E de como assim tenham acordado, obrigam a respeitar e fazer cumprir e respeitar o rumo aberto pelo engenheiro Manoel Accioli Ferreira da Silva e constante do atestado pelo mesmo, passado e assinado o presente (rasuras) para que se tenha inteiro valor a demarcação (rasuras) e que tem do seu julgador por sentença do juiz competente, o referido acordo de demarcação e limites das terras, ou como adiante (rasuras) mandado lavrar esta escritura que depois de por mim lhes ser lida e por eles outorgada e aceita, eu tabelião a outorguei e aceitei a bem dos ausentes e mais pessoas a quem interessar possa.

E de como assim outorgado e dou fé abaixo assinam com as testemunhas presentes:

Joaquim Jerônimo Santos Barbosa e Amorim Alves Franco; Epifânio Francisco de Oliveira, assinando a rogo de dona Maria Joaquina de Jesus, Antônio França de Oliveira. A rogo de Rita Cazumbá, coronel Antônio Carlos Pedreira; a rogo de Gonçalo Cardoso Cazumbá, José Machado Cerqueira da Silva; a rogo de Joana Cazumbá, Luiz Cazumbá; Tibúrcio Alves Barreiros. A rogo de Maria Guilhermina Barreiras, José Calisto Joaquim Jerônimo dos Santos Barbosa; Amorim Alves França; Epiphanio Ferreira de Oliveira.

Lindolfo da Silva Machado - escrivão.

Pague desta diligência a condição de quarenta mil réis.

São Gonçalo dos Campos, 29 de agosto de 1903 [...] (FMJM-SGCBA, 1903)

Ambas as peças processuais apontam para a delimitação efetiva e jurídica das propriedades na região denominada Cruz, e que os rumos antigos foram alterados a 
igualdade com aquelas pessoas cujos antepassados não passaram pela experiência da escravidão. Malgrado a Lei de 13 de maio de 1888, os descendentes de escravos continuaram a ser vistos como cidadãos de segunda categoria, porque não houve uma política de equidade que Ihes proporcionasse uma efetiva integração na sociedade. $O$ abolicionista Joaquim Nabuco já havia advertido no bojo do movimento abolicionista: "não basta acabar com a escravidão, é preciso destruir sua obra". A questão agrária no Brasil tem sido até os dias de hoje uma das obras da escravidão que ainda não foram destruídas. A manutenção do latifúndio exclui muitos da plena cidadania, entre eles, os descendentes dos egressos da escravidão. A luta da população remanescente de quilombos e das comunidades tradicionais é um indício da permanência de estruturas advindas da sociedade escravista.

As terras, após a demarcação efetivada no ano de 1903, quando os Cazumbá tiveram a primeira intervenção jurídica sobre o território adquirido pelo ancestral João Cardoso Cazumbá, no ano de 1879, em parceria com Manoel Ferreira de Cerqueira, na localidade denominada Sobrado, que já fora também chamada de Várzea, com a nova demarcação, receberam outras denominações: Fazenda Terra Dura, Fazenda Cruz e Fazenda Cazumbá.

Observando o croqui de vários ângulos, os destaques são para as fazendas Cruz, parte superior (norte) e fazenda Terra Dura, faixa inferior (sul). A fazenda Cazumbá fica no corredor ao meio, entre o Rio Jacuí e a Estrada de Ferro Central (a leste), o lago Tanquinho, à direita. Destaque também para a cerca pertencente a Odilon Borges, junto à linha pontilhada, entre o ponto de partida e o lago Tanquinho. Estrada de Ferro Central a leste.

Linha superior contínua: rumo de acordo entre os proprietários das Fazendas Cruz, Cazumbá e Terra Dura. Linha inferior, pontilhada: rumo que devia prevalecer de acordo com os limites contidos nas escrituras. O croqui aponta para a ampliação das terras da Fazenda Terra Dura (FMJM-SGCBA, 1903). 
Figura 1: Croqui dando uma visão geral da demarcação das terras no ano de 1903

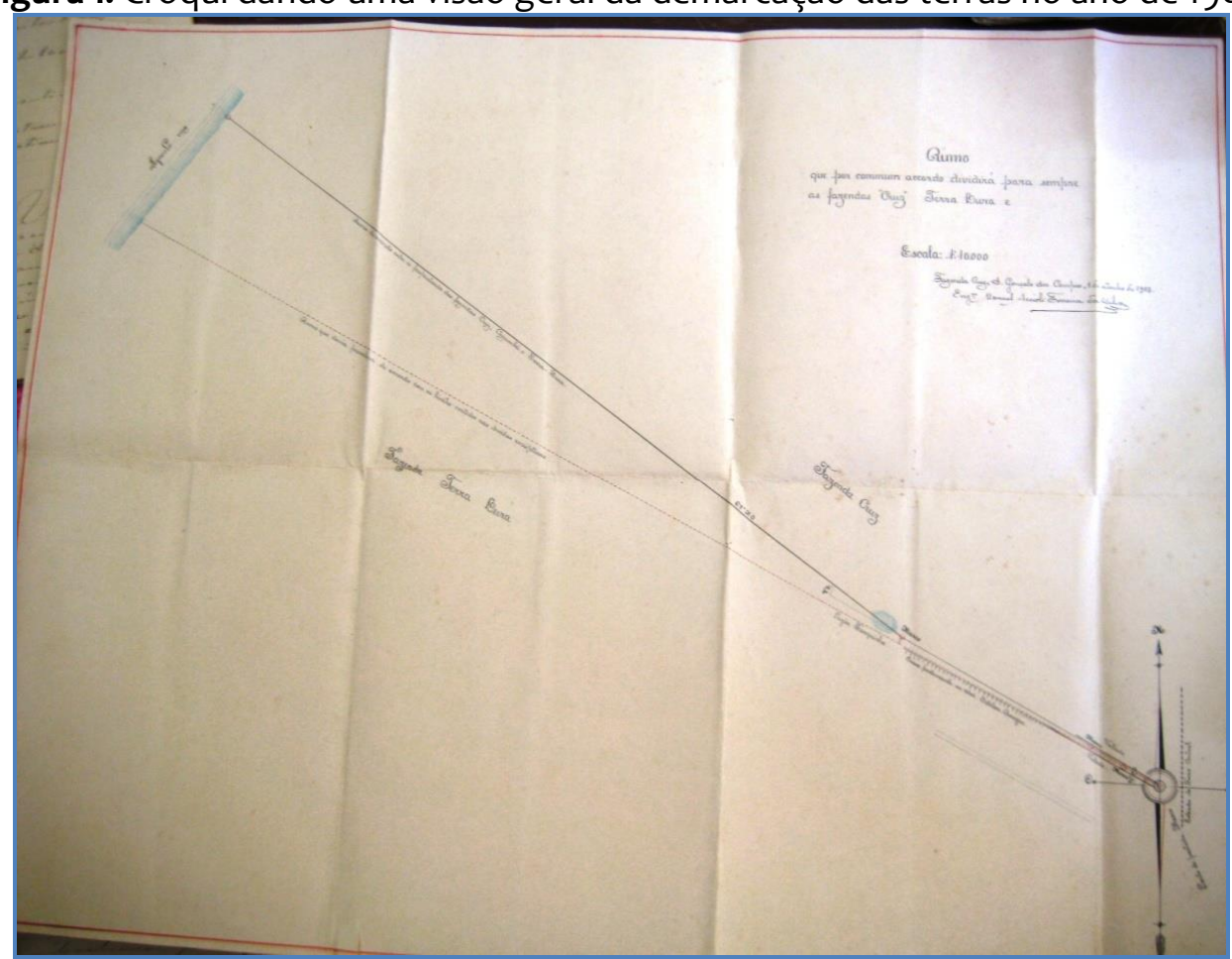

Fonte: foto produzida pelo autor.

Figura 2: Ângulo focalizando a visão da parte central e leste: cerca de Odilon Borges, valado na parte sul (fazenda Terra Dura), valado parte norte (Fazenda Cruz). Marco de partida e Estrada de Ferro Central.

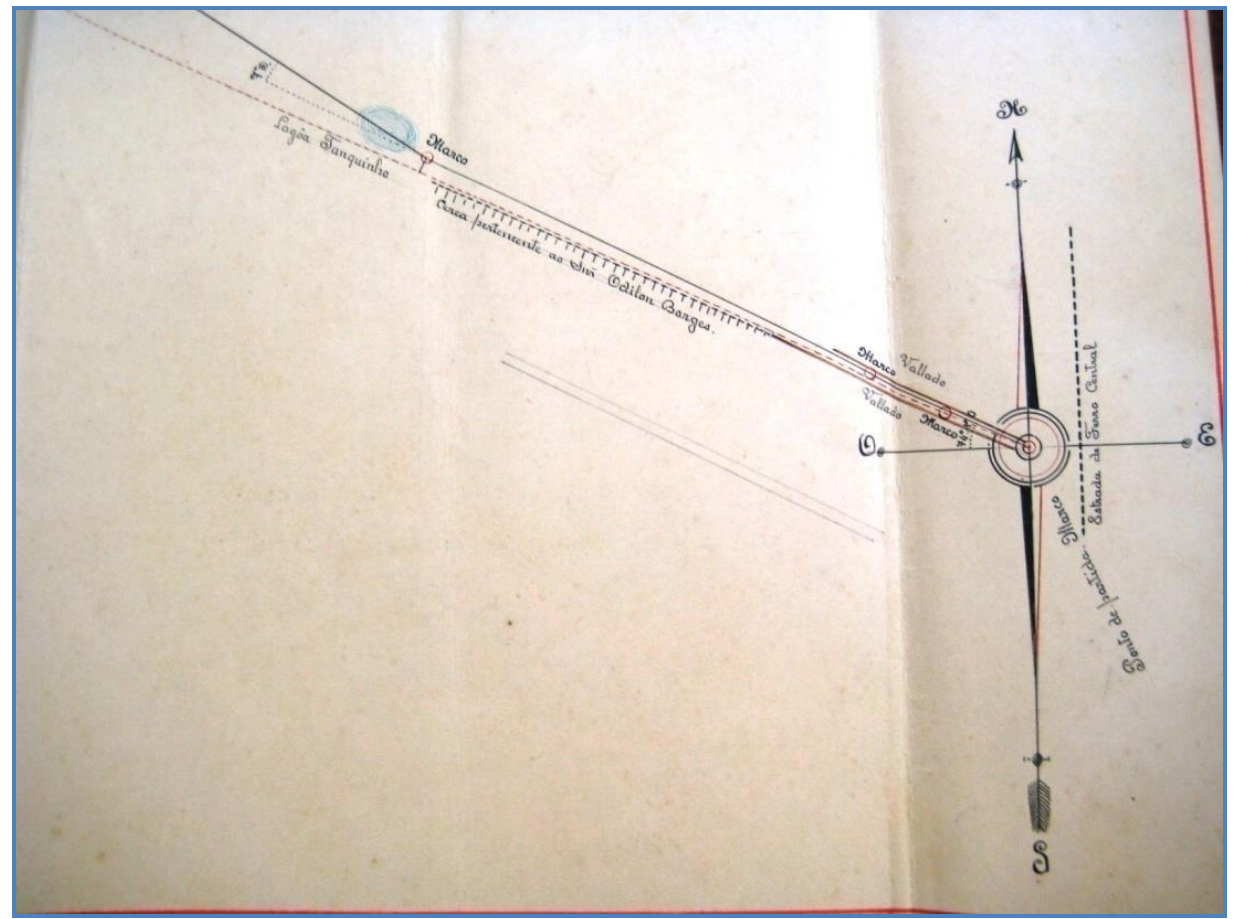

Fonte: foto produzida pelo autor. 
Figura 3: Ângulo focalizando a parte oeste, onde se encontra o Rio Jacuípe. Linha inferior, pontilhada, a nova fronteira entre a Fazenda Terra Dura e terras Cazumbá. Linha contínua, acima, dividindo as Terras entre Cazumbá e Fazenda Cruz.

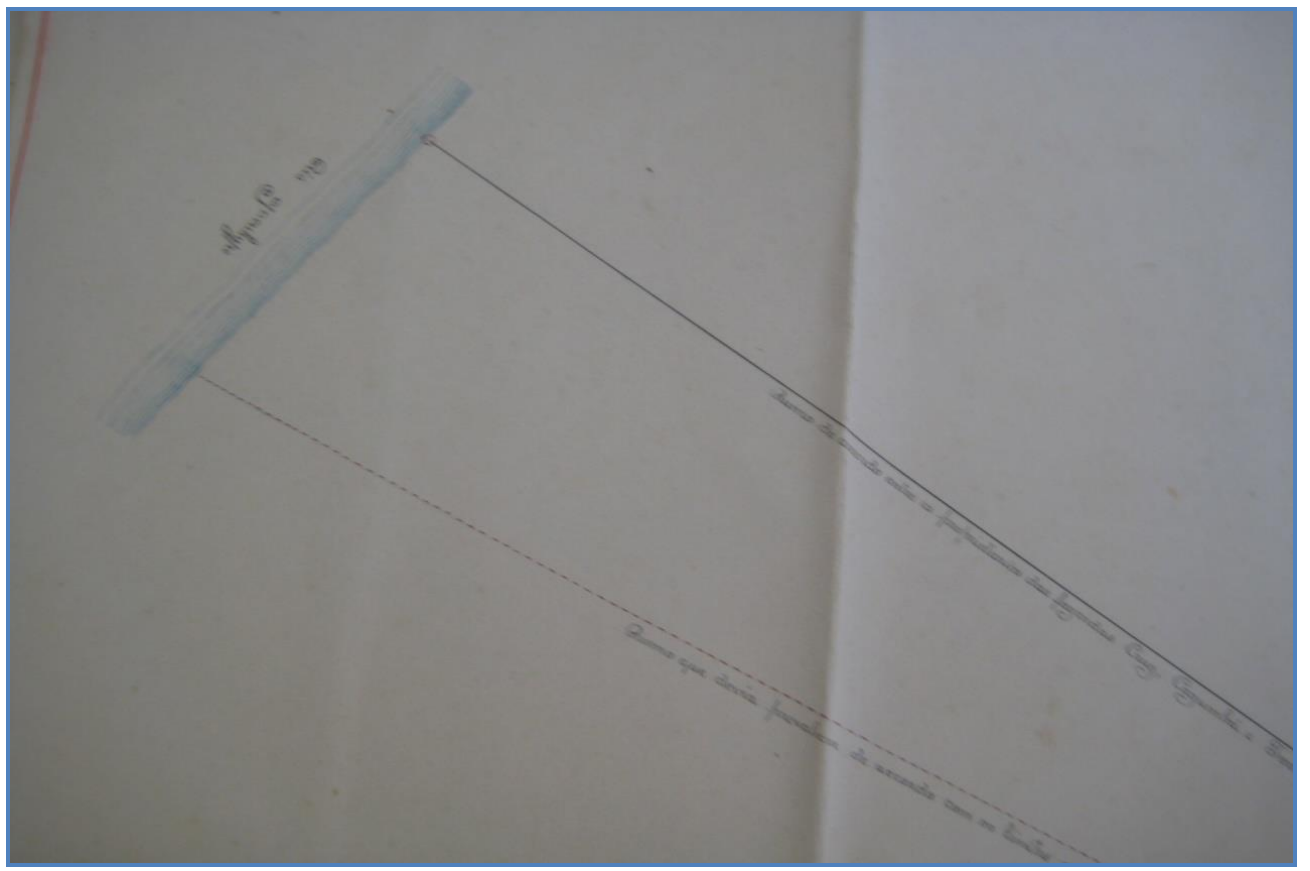

Fonte: foto produzida pelo autor.

Ana Regina, uma das poucas Cazumbá que ficaram nas terras dos antepassados, narra memórias a partir da infância, descrevendo o território Cazumbá, o trabalho nas plantações do avô e do pai, a passagem do trem e os acenos para os que iam e vinham de Cachoeira para Salvador ou Feira de Santana. O mesmo trem que ia e vinha levando e trazendo alegria também deixava saudades. Talvez por isso as lembranças da descendente aflorem com mais intensidade quando provocadas, como fizemos, no intuito mesmo de refazer um passado que não volta. E Ana Regina Cazumbá contou-nos do passado entre risadas, suspiros, entonações de voz e silêncios. Usou bastante a exclamação “Ave, Maria!" quando as palavras pareciam não expressar toda a emoção de refazer o passado.

Enquanto Regina descreveu com precisão parte do território Cazumbá, ao falar das festas, do trabalho, das brincadeiras, "de um tempo que não volta mais", o documento jurídico não nos forneceu muitas informações sobre as terras Cazumbá. Encontramos mais referências sobre as terras das outras fazendas no croqui elaborado pelo engenheiro Manoel Accioli Ferreira da Silva, responsável pela demarcação e 
elaboração do memorial. O resumo do memorial é um exemplo desse "esquecimento", quando anuncia no canto direito da margem superior: "resumo que por comum acordo dividirá para sempre a fazenda Cruz, Terra Dura e". A Fazenda Cazumbá não foi anunciada. Apenas esquecimento?

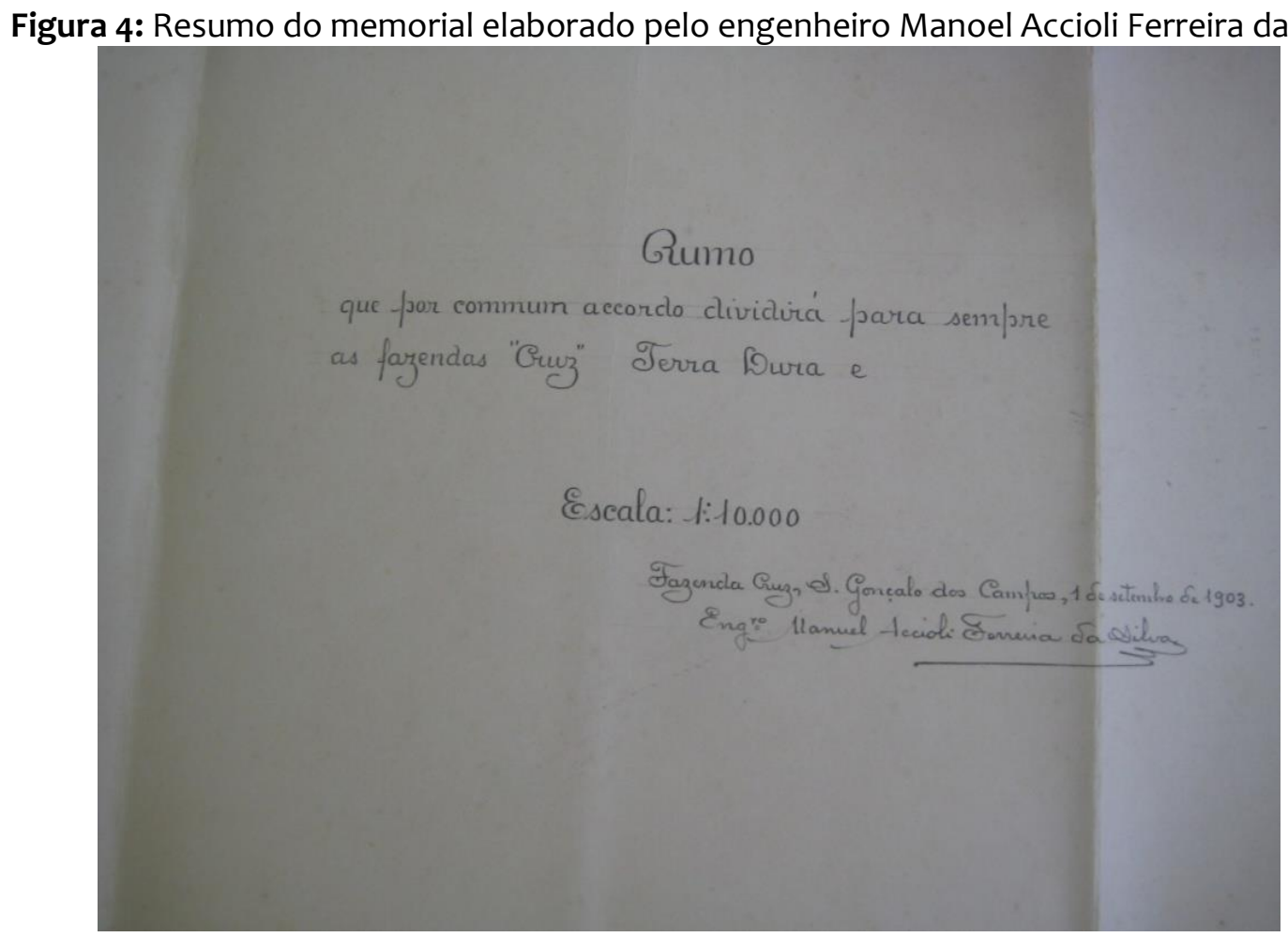

Fonte: foto produzida pelo autor.

O intertítulo desta seção - 1903: "o ano que não acabou" - foi uma alusão à ficção do escritor George Orwell para caracterizar que a referida demarcação afetou definitivamente o território Cazumbá, possibilitando a dispersão da família e a consequente perda das terras de diferentes formas. Por exemplo, foi um ano após a demarcação das terras, em 1904, que Vicente Cardoso Cazumbá e sua esposa, Theodora Lima Cazumbá, hipotecaram suas propriedades e nunca mais as recuperaram. É o que atesta a escritura pública lavrada:

[...] Escritura pública de débito, obrigação e hipoteca que fazem Vicente Cardozo Cazumbá e sua mulher Theodora Lima Cazumbá, e como credor da hipoteca, o cidadão Francisco José Pedreira, na quantia de um conto e setecentos mil réis [...] 
Saibam todos quanto este público instrumento de escritura pública de débito, obrigação e hipoteca virem, que sendo o ano de 1904, aos 5 dias do mês de julho do dito ano, nesta cidade de São Gonçalo dos Campos, comarca de cachoeira, no sítio denominado Canto Bom, onde eu tabelião a chamado vim, ali compareceram partes justas outorgantes, a saber como hipotecantes Vicente Cardozo Cazumbá e sua mulher Theodora Lima Cazumbá e o credor hipotecário Francisco José Pedreira, moradores deste termo, conhecidos dos próprios e de mim tabelião, do que tudo dou fé. E logo pelo hipotecante Vicente Cardozo Cazumbá e sua mulher Theodora Lima Cazumbá. [...] (FMJM-SGCBA, anos 1903-1904, folha 7v)

\section{Sobrenome Cazumbá: “capital simbólico”, patrimônio da cultura imaterial}

No Brasil, uma das formas de distinção social é o sobrenome, este geralmente relacionado com os bens materiais herdados dos antepassados (bens de raiz). No passado, os herdeiros masculinos eram os denominados "homens de bem". A eles estava “destinado" um lugar ao sol na sociedade, calcada no latifúndio e na escravidão. Alguns, malgrado não serem descendentes da aristocracia advinda de além-mar, receberam condecorações como barões, condes e duques, entre outras. Outra categoria social de distinção, sobretudo no Império e início da República, foi o título de coronel. No meio urbano, o título de doutor, sobretudo para os bacharéis em Direito.

Não é necessário dizer que, apesar de a população brasileira de ontem e de hoje ser composta majoritariamente por descendentes de africanos, estes não foram agraciados com tais títulos (salvo raríssimas exceções), até porque a História do Brasil foi escrita através da ótica do colonizador. Mesmo os africanos e descendentes que se destacaram "no mundo dos brancos" ficaram por um longo tempo na invisibilidade, quando não foram branqueados. Ou seja, deram a eles feições de brancos e seus novos sobrenomes não indicavam mais a origem africana, já que, em decorrência do processo do tráfico, os africanos perdiam sua identidade coletiva e individual. Há exceções, como o aqui abordado. No campo da História dos afrodescendentes no Brasil, a manutenção do sobrenome africano constituiu-se uma peculiaridade. É o caso da família Cazumbá.

As primeiras informações acerca da família Cazumbá, obtivemos a partir de um congresso com a temática africana e afro-brasileira, no contexto em que se discutiam as pesquisas, as fontes e a historiografia da referida população. É preciso dizer que as 

inclusive uma avenida no centro da cidade com esse sobrenome.

A partir das pistas, fomos a campo. Ao desembarcamos na rodoviária da cidade de São Gonçalo, pedimos informações sobre dona Judite que, pensávamos, pudessem nos apresentar à família Cazumbá. Não sabíamos que a pessoa que indicou onde ela morava era um Cazumbá, embora quando perguntamos pelos Cazumbá, ele se fizera de desentendido por algum motivo. Aliás, ele perguntou se éramos da família Cazumbá. E mais, a grande Avenida Cazumbá estava ali, à nossa frente, se bem que só a observamos depois, quando nos descreveram o local onde ficava a propriedade de Luiz Cardoso Cazumbá e sua esposa Lélia Gomes Cazumbá, referências dessa família distinta, que, apesar de não ter recebido nenhuma condecoração, era, segundo uma depoente, "uma família de brasão, não fosse assim, não teria nome de rua numa cidade, ainda que no interior da Bahia".

Começaremos, então, por esse depoimento que nos indica a distinção dos descendentes dos Cazumbá, tanto pelo sobrenome, quanto pelos bens que tiveram no passado na cidade de São Gonçalo dos Campos, no já mencionado Recôncavo Baiano, cidade que no passado recebeu um contingente de africanos na condição de escravizados para o trabalho compulsório, sobretudo na cultura fumageira. Entre eles, um contingente de falantes da língua banta, ou seja, africanos da África Centro-Ocidental.

Na ocasião do depoimento, Rosa de Lima Cazumbá Gomes estava com o filho Anderson Cazumbá, “Andinho”, que havia indicado a dona Judite em São Gonçalo dos Campos e que havia mencionado a Avenida Cazumbá. Em meio à entrevista, que na verdade foi um diálogo, conforme sugestões metodológicas, ela fez uma afirmação seguida de uma interrogação:

[...] Eu tenho uma amiga que vem aqui e ela me disse:

- 'Rosa, o nome de vocês é de brasão'! O que é brasão, professor? [Explicamos o significado] 
Sabe por que ela diz isso? É porque em São Gonçalo tem a rua com o nome da gente.

Ela disse: ‘- O nome de vocês é de brasão’!

Eu perguntei:

- Por que, Zeca?

- 'Por que tem nome em rua! É nome de brasão'.

Agora estou entendendo o que é nome de brasão! Veja, aqui tem rua com o nome de Antônio Carlos Magalhães, Avenida Tancredo Neves, Getúlio Vargas... Pessoas importantes, gente de posse.

Então nós que não tivemos estas condições todas, temos o nome de rua numa cidade do interior da Bahia $[\ldots]^{14}$

Rosa de Lima Cazumbá Gomes lembrou com orgulho alguns personagens e o lugar de distinção que eles ocupavam na cidade de São Gonçalo dos Campos. Suas lembranças são a partir da infância, quando tinha mais ou menos dez anos de idade. Muita coisa lhe escapou, pois a memória é seletiva e ficou aquilo que teve significado. Podemos pensar, no caso dela, na relação entre a memória e o sagrado, as festas religiosas de Nossa Senhora da Boa Morte, nas quais a presença dos Cazumbá era marcante; iam à frente, bem-vestidos, com roupas feitas para a ocasião, como lembraram outras entrevistadas. Para ocupar tais lugares, era necessário um certo poder econômico em virtude dos gastos. Os festeiros, como eram chamados, eram responsáveis pelo banquete. Aliás, uma das características das denominadas Festas do Santo dos Pretos.

[...] Quando tinha procissão, os Cazumbá queriam ir na frente, os andaimes nos ombros, roupa branca em diagonal, bem bonito, chapéu bonito.[...] Quem tinha roça para cuidar, ia cuidar; senão armazém, armazém de fumo [...] meu pai trabalhava no fumo, depois de um tempo, foi trabalhar no Ginásio Polivalente como vigilante. Meus tios tinham fazendas: uns tinham fazendas enormes, outros tinham meias fazendas que eram pequenas $[\ldots]^{15}$

Maria da Invenção Cazumbá, conhecida como Martina da Boa Morte, é uma das lideranças atuais da organização da Festa de Nossa Senhora da Boa Morte, que acontece todo ano no mês de agosto. Ela nos contou sobre as dificuldades encontradas hoje, a falta de apoio das pessoas e mesmo das instituições. Falou do presente tendo como

\footnotetext{
${ }^{14}$ Entrevista com Rosa de Lima Cazumbá Gomes, 72, realizada na cidade de Salvador (BA) em 24 de maio de 2014.

${ }^{15}$ Entrevista com Rosa de Lima Cazumbá Gomes.
} 
referência as festas que vivera no passado, tecendo uma relação entre o presente e o passado da Festa e dos Cazumbá:

[...] A irmandade quem começou foi minha avó, Maria Bilô e Felismina [...] Naquele tempo, a festa era oito dias, não era como hoje. Não era a Lira, era samba. [...] Naquele tempo, era samba, batia tambor; hoje não se faz isso. A Lira só tocava na procissão. Nas casas era samba, amanhecia sambando [...] Cada dia, a Nossa Senhora ficava na casa de uma pessoa. Aí tinha a reza do terço, a novena, o ofício, cada dia era uma coisa. Aí, depois que acabava de rezar, tinha o samba, tinha comida: um dia era arroz, outro munguzá, feijoada... era fazendo assim! Agora são só três dias na igreja. Tem a missa, a procissão, depois tem a festa na casa da pessoa [...] No meu tempo, no tempo em que alcancei, na irmandade tinha: Antônia Cazumbá, Cecília Cazumbá, Lola Cazumbá.Tem uma filha da Antônia que ficou no lugar dela $[\ldots]^{16}$

A memória do sagrado é também muito presente na memória de dona Martina, tanto quanto na de dona Ana Regina Cazumbá. Ambas lembraram que havia uma fronteira muito tênue entre o sagrado da cristandade e o sagrado de matriz africana, ou melhor, havia uma intersecção dentre elas. Enquanto uma era realizada mais no espaço da rua, do público, a outra, por passar-se no espaço do privado, da casa dos festeiros, onde havia o samba, permitia que os espíritos ancestrais baixassem. Já na rua, o ritual era mais ao estilo católico, inclusive com a banda da cidade, a Lyra:

[...] Muitos Cazumbá frequentavam candomblé, iam nas casas, mas não eram pais de santo não. Faziam em suas casas, chamavam as pessoas para fazerem em casa deles. Faziam na casa deles mesmo. Meu sogro e minha sogra faziam na casa deles. Faziam novena, festa de Ogum... faziam festa mesmo! [... $]^{17}$

[...] Quando acabava a novena, tinha o samba. Acabava o samba, só via negro caindo e rolando. Chegava o santo, baixava os santo [risos] Hoje em dia, não tem isso mais! Tinha uma que morava nas Pedrinhas, eu já era casada, me chamou para ir na novena. Depois tinha o samba, os caboclos desciam, dançavam, dançavam. A gente ficava com pena, porque uns que desciam jogavam as pessoas no chão, batia a cabeça.

De menina e mocinha a gente não ia, mas depois de casada a gente ia. $O$ marido ia junto. Quando casei, eu já tinha 30 anos [... $]^{18}$

\footnotetext{
${ }^{16}$ Entrevista realizada com Maria da Invenção Cazumbá (Martina da Boa Morte), 78 anos, na cidade de São Gonçalo dos Campos (BA) em 27 de fevereiro de 2011.

${ }^{17}$ Entrevista realizada com Maria da Invenção Cazumbá (Martina da Boa Morte), 78 anos, na cidade de São Gonçalo dos Campos (BA) em 27 de fevereiro de 2011.

${ }^{18}$ Entrevista realizada com Ana Regina Cazumbá de Queiróz, 79 anos, na cidade de São Gonçalo (BA, em 3 de fevereiro de 2011.
} 
O lugar na festa era um símbolo de distinção. O traje e a "ostentação" também denotavam um diferencial, se comparados com os demais descendentes de escravizados. Logo que chegamos a São Gonçalo, ouvimos vários depoimentos que apontavam para a distinção dos Cazumbá em relação aos outros negros. O ex-secretário da educação e um dos memorialistas da cidade foi um dos que falaram do lugar dos Cazumbá na História da cidade:

[...] Eu era garoto, tinha mais ou menos quinze anos de idade, lembro-me de quando Dona Lélia passava na rua, era uma atração, todo mundo admirava. Era muito bonita, tinha uma altivez... Era muito respeitada, era uma negra, mas muito respeitada. Tinha um chácara nas proximidades de onde hoje é o estádio de futebol [...]. Os Cazumbá sempre foram pessoas muito consideradas em São Gonçalo $[. . .]^{19}$

Quem também lembrou de Lélia Gomes Cazumbá foi Martina da Boa Morte. Aliás, a narrativa dela, que pode parecer exagerada, reflete a representação que os Cazumbá tinham na época. Aliás, o seu marido, Luiz Cardoso Cazumbá, foi um negociante renomado da cidade, com várias propriedades, como veremos adiante. Pois bem, Martina se lembrou da ostentação de Lélia e do filho Eufrásio, conhecido como Fafá. Ela, que fora casada com um Cazumbá, contou-nos que: “[...] eu fui casada com Cazumbá, mas naquele tempo os antigos não davam trela, se chegasse na casa eles estivessem lá dentro, não vinham atender. Os negros [Cazumbá] só andavam de linho, bem arrumados, como doutores! Sapato branco nos pés! [...]".

E continuou:

[...] Na família Cazumbá, tem padre, advogado, vereador, professor... tem tudo. Que no princípio os Cazumbá eram ricos depois é que foram morrendo, foram perdendo... [Acrescenta]: aqui tem uma avenida que é o nome Cazumbá, porque estas terras eram todas deles. Tinha um que era tão orgulhoso que a roupa dele só era lavada com sabonete, era o Fafá Cazumbá, era filho da Lélia Cazumbá. Dizem que ele morreu intoxicado por perfume... Lélia era uma morena clara, bonita, muito orgulhosa, nos dedos dela só se via anéis e ouro. Eu a conheci, eu deveria ter uns quinze anos de idade, mais ou menos. Os negros Cazumbá eram todos arrumados... eu casei com Mathias Cazumbá, o pai dele era Manoel Cazumbá. Meu sogro mesmo tinha fazenda, gado, porco, galinhas, terras

\footnotetext{
${ }^{19}$ Entrevista realizada com Edivaldo da Silva Daltro, 69 anos, na cidade de São Gonçalo dos Campos (BA) em $1^{\circ}$ de fevereiro de 2011.
} 
Mesmo com a perda do patrimônio material, como apontam os depoimentos, a [...] Naquele tempo Cazumbá andava de linho branco, sapato branco no pé, como doutores... Acabou-se os Cazumbá mais velhos, jogaram tudo fora, acabou-se tudo $[\ldots]^{20}$

família Cazumbá, no Recôncavo Baiano, sobretudo, na cidade de São Gonçalo dos Campos, mantém a distição social herdada dos antepassados, embora os mais jovens afirmem que às vezes passaram por constrangimentos na escola por terem um sobrenome diferente, "exótico", se comparado com os dos demais. Mas constatamos que se orgulharam quando ouviram um pouco da História dos antepassados.

Há na extensa família Cazumbá alguns que, por algum motivo, não herdaram o sobrenome. Deles ouvimos o desejo de "assinar" Cazumbá, principalmente os que conhecem as políticas afirmativas implementadas nos últimos anos, como, por exemplo, as cotas étnico-raciais. Ou seja, afirmar-se como descendentes de africanos com sobrenome Cazumbá é um capital simbólico, mesmo que não haja, hoje, o patrimônio material havido no passado.

\footnotetext{
${ }^{20}$ Entrevista com Maria da Invenção Cazumbá.
} 


\section{Referências}

\section{Fontes primárias (manuscritas)}

ARQUIVO PÚBLICO DO ESTADO DA BAHIA. Registro Civil. Escritura de Perfilhação.

Tabelião: Luciano de Carvalho Marbak. Cartório: 90. Livro 1294.

FÓRUM MINISTRO JOÃO MENDES DE SÃO GONÇALO DOS CAMPOS ( Bahia). Processo do ano de 1903. Demarcação das terras dos descendentes de João Cardoso Cazumbá.

FÓRUM MINISTRO JOÃO MENDES DE SÃO GONÇALO DOS CAMPOS(Bahia). Tabelionato de Notas com Funções de Protesto de São Gonçalo dos Campos. Livro n. 2, anos 18791881. São Gonçalo Dos Campos, 1879-1881.

FÓRUM MINISTRO JOÃO MENDES DE SÃO GONÇALO DOS CAMPOS ( Bahia). Tabelionato de Notas com Funções de Protesto de São Gonçalo dos Campos. Livro n. 4, anos 18831886. São Gonçalo Dos Campos, 1883-1886.

FÓRUM MINISTRO JOÃO MENDES DE SÃO GONÇALO DOS CAMPOS ( Bahia). Tabelionato de Notas com Funções de Protesto de São Gonçalo dos Campos. Livro n. 8, anos 18871891: (Certidão de Perfilhação). São Gonçalo Dos Campos, 1887-1891.

FÓRUM MINISTRO JOÃO MENDES DE SÃO GONÇALO DOS CAMPOS (Bahia). Tabelionato de Notas com Funções de Protesto de São Gonçalo dos Campos. Livro 13, anos 1895-1896. São Gonçalo Dos Campos, 1895-1896.

FÓRUM MINISTRO JOÃO MENDES DE SÃO GONÇALO DOS CAMPOS (Bahia). Tabelionato de Notas com Funções de Protesto de São Gonçalo dos Campos. Livro 15, anos 1898-1899. São Gonçalo Dos Campos, 1898-1899.

FÓRUM MINISTRO JOÃO MENDES DE SÃO GONÇALO DOS CAMPOS ( Bahia). Tabelionato de Notas com Funções de Protesto de São Gonçalo dos Campos. Livro 20, anos 1903-1904. São Gonçalo Dos Campos, 1903-1904.

\section{Fontes orais (Entrevistas)}

Ana Regina Cazumbá de Queiróz, 79 anos, realizda na cidade de São Gonçalo dos Campos (BA) em 3 de fevereiro de 2011. 
Carmosina Brites de Oliveira, realizada na cidade de São Gonçalo dos Campos (BA), na localidade da Cruz, em 3 de fevereiro de 2011.

Edivaldo da Silva Daltro, 69 anos, realizada na cidade de São Gonçalo dos Campos (BA) em $1^{\circ}$ de fevereiro de 2011.

Maria da Invenção Cazumbá (Martina da Boa Morte), 78 anos, realizada na cidade de São Gonçalo dos Campos (BA) em 27 de fevereiro de 2011.

Rosa de Lima Cazumbá Gomes, 72 anos, realizada na cidade de Salvador(BA) em 24 de maio 2014.

\section{Livros, dissertações e teses}

FREIRE, Luiz Cleber Morais. Nem tanto ao mar, nem tanto à terra: agropecuária, escravidão e riqueza em Feira de Santana, 1850-1888.2007. Dissertação (Mestrado em História) - Programa de Pós-Graduação em História (PPGH), Universidade Federal da Bahia (UFBA), Salvador, 2007.

LESSA, Luciana Falcão. Senhoras do Cajado: um estudo sobre a irmandade da Boa Morte de São Gonçalo dos Campos - Bahia (1900-1950). 2005. Dissertação (Mestrado em História) - Programa de Pós-Graduação em História (PPGH), Universidade Federal da Bahia (UFBA), Salvador, 2005.

SILVA, Elizabete Rodrigues da. Fazer charutos: uma atividade feminina. 2001. Dissertação (Mestrado em História). Programa de Pós-Graduação em História (PPGH), Universidade Federal da Bahia (UFBA), Salvador, 2001.

VERGER, Pierre. Fluxo e refluxo: o tráfico de escravos entre o Golfo do Benin e a Bahia de Todos os SANTOS dos séculos XVIII e XIX, 1987. São Paulo:Corrupio, 1987.

\section{Periódicos}

JORNAL ITAJAHY. Itajai: Arquivo Público de Itajaí (SC), 17 de maio de 1884.

\section{Sites eletrônicos}

NÚCLEO PIRATININGA DE COMUNICAÇÃO LINGUAGEM. Os narradores mudos de Javé. Publicado em 15 de maio de 2006. Disponível em: <http://nucleopiratininga.org.br/osnarradores-mudos-de-jave/>. Acesso em: 21 mar. 2015. 
http://www.forumimobiliario.com.br/2011/01/os-servicos-prestados-pelos-tabelionatos-denotas-e-pelos-cartorios-de-registro-de-imoveis/.

http://www.piratininga.org.br/novapagina/leitura.asp?id_noticia=64\&topico=Linguagem.

http://www2.camara.leg.br/legin/fed/decret/1824-1899/decreto-3316-11-junho-1887-542925publicacaooriginal-52597-pl.html 